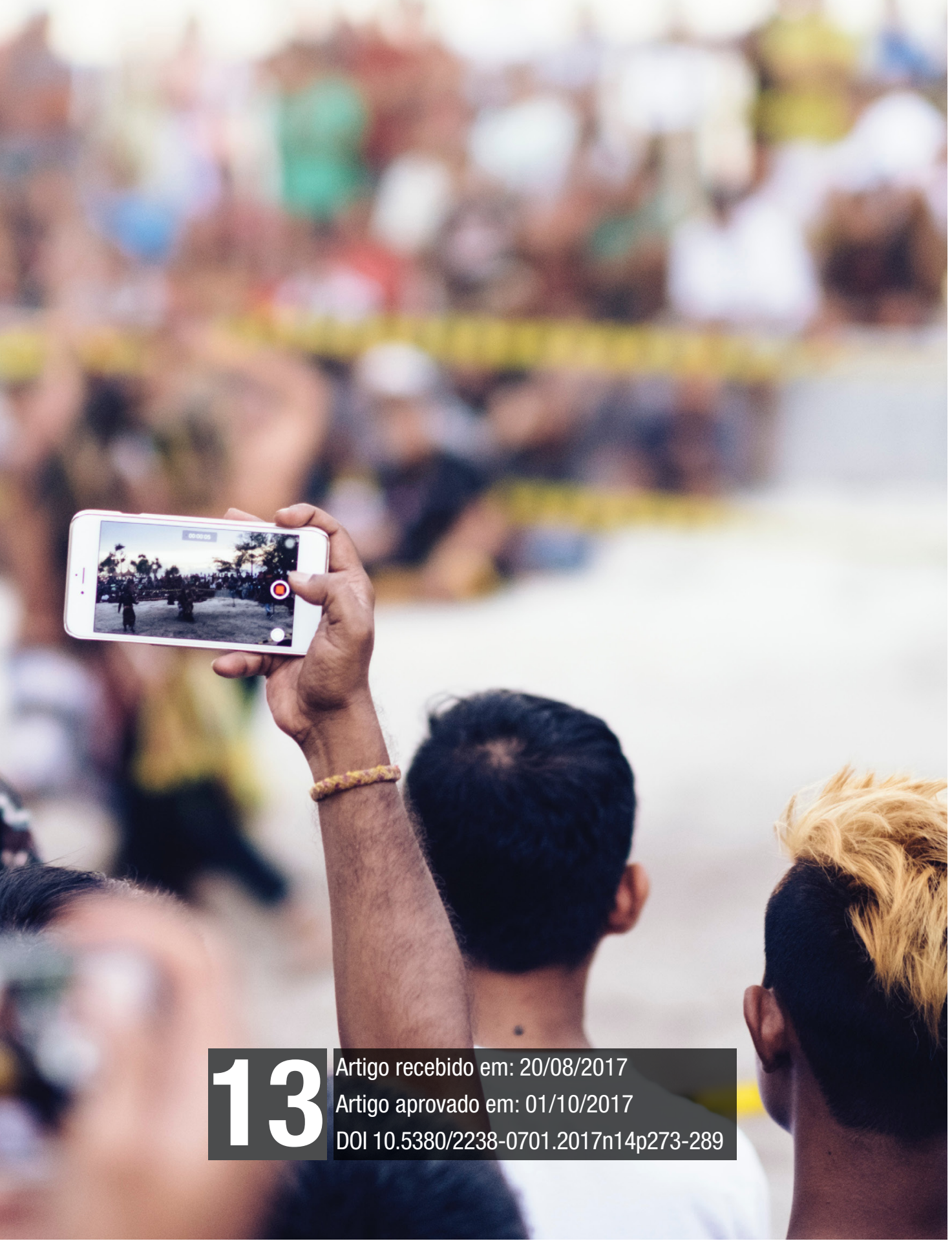


Cultura de marca. Consumidor-marca. Branding na era digital. 


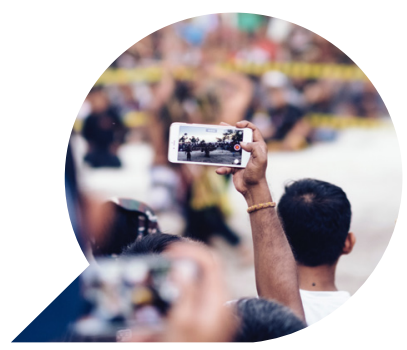

\title{
O consumo de causas sociais na era da midiatização digital
}

\author{
The consumption of social causes in the \\ age of digital mediatization
}

\author{
El consumo de causas sociales en la era de la \\ midiatización digital
}

\section{VALÉRIA BRANDINI*}

Resumo: Este artigo foi desenvolvido a partir dos resultados de pesquisa de pós doutorado realizada na ECA - USP, intitulada "A Era das Causas: O Propósito como Capital de Valor na Publicidade" BRANDINI (2016), onde investigamos pela metodologia de pesquisa em Midiatização desenvolvida por Andreas Hepp (2015), como a internet alterou a relação entre consumidores e marcas e suscitou uma aderência a causas sociais como estratégia de branding. Como resultado, obtivemos os conteúdos trabalhados no presente artigo, abordando como a relação entre marcas e consumidores rearticulou-se sensivelmente a partir do advento da cultura digital e o consumidor passou de receptor passivo da informação (era do broadcast), a produtor ativo na ressignificação dos conteúdos das marcas via internet. Nesse contexto, o

\footnotetext{
* Pós Doutora pela Universidade de São Paulo. Doutora pela USP / Universitá La Sapienza. Integrante do GESC3 - Grupo de Estudos Semióticos em Comunicação, Cultura e Consumo. Universidade de São Paulo - USP. Email: valeria@valeriabrandini.com / vbrandin@usp.br
} 
protagonismo do consumidor, numa relação onde este também percebe-se como uma marca, fez com que cada vez mais as marcas buscassem novas estratégias de construção de imagem, com uma abordagem mais humanizada, pautada em pressupostos ideológicos e de políticas sociais, para criar formas de engajar este consumidor, cada vez mais critico e exigente, não apenas em termos de produto, mas de idoneidade, transparência e veracidade. Assim, o engajamento em causas - ou a "produção delas" como estratégias de construção de imagem de marca, tornou-se um recurso cada vez mais em voga, contudo, uma estratégia sensível e passível de erros que podem comprometer a imagem da marca que a adota.

Palavras-chave: Era das Causas; Midiatização Digital; Cultura de Marca; Consumidor-Marca; Branding na Era Digital.

Abstract: The relationship between brands and consumers changed considerably with the advent of digital culture. The consumer turned from passive receiver of information (age of broadcast), to active producer in the reframing of the brands via internet content. In this context, the consumer role in a relationship where he/she is also perceived as a brand, has made more and more brands seek new image-building strategies with a more humane approach, based on ideological assumptions and social policies, to create ways to engage this consumer, increasingly critical and demanding, not only in terms of product, but integrity, transparency and truthfulness. Thus, engagement in causes - or "production of them" as strategies for building brand image, has become a feature increasingly in vogue, however, a sensitive and error-prone strategy that can compromise the image of the brand adopts.

Keywords: The Era of Causes; Digital Midiatization; Branding Culture; Consumidor-Brand; Branding in the Digital Age.

Resumen: Este artículo fue desarrollado a partir de los resultados de investigación de post doctorado realizada en la ECA - USP, titulada "La Era de las Causas: El Propósito como Capital de Valor en la Publicidad" BRANDINI (2016), donde investigamos por la metodología de investigación en Midiatización desarrollada por la "Andreas Hерp (2015), como la Internet alteró la relación entre consumidores y marcas y suscitó una adherencia a causas sociales como estrategia de branding. Como resultado, obtuvimos los contenidos trabajados en el presente artículo, abordando cómo la relación entre marcas y 
consumidores se reorganizó sensiblemente a partir del advenimiento de la cultura digital y el consumidor pasó de receptor pasivo de la información (era del broadcast), el productor activo en la resignificación de los contenidos de las marcas a través de Internet. En este contexto, el protagonismo del consumidor, en una relación donde éste también se percibe como una marca, ha hecho que cada vez más las marcas busquen nuevas estrategias de construcción de imagen, con un enfoque más humanizado, pautado en supuestos ideológicos y de politicas sociales para crear formas de involucrar a este consumidor, cada vez más crítico y exigente, no sólo en términos de producto, sino de idoneidad, transparencia y veracidad. Así, el compromiso en causas o la "producción de ellas" como estrategias de construcción de imagen de marca, se ha convertido en un recurso cada vez más en boga, sin embargo, una estrategia sensible y pasible de errores que pueden comprometer la imagen de la marca que la adopta.

Palabras clave: Era de Las Causas; La Mediatización Digital; Cultura de Marca; Consumidor-Marca; Branding en la Era Digital. 


\title{
Protagonismo do consumidor e marcação identitária na era das causas
}

A dinâmica da relação entre consumidor e marcas, sua relação com o universo de bens e seus significados (mediada pela imagem de marca construída pela publicidade) é descrita pelo antropólogo do consumo Grant McCracken (2003) como uma estrutura móvel de pólos de emissão e recepção de significados culturais dos bens, constantemente em trânsito, absorvidos do mundo social, codificados em bens e fluindo por meio da comunicação publicitária em direção às suas diversas localizações no mundo social do consumo, com base no esforço coletivo de agentes como designers, publicitários e também consumidores, que fornecem a matéria prima simbólica do mundo socialmente constituído.

Conforme o autor, neste sistema móvel, os significados oriundos do mundo social são absorvidos pela indústria e transportados para os bens, que expressam tanto categorias culturais - quando atribuídos de significados que distinguem categorias culturais como idade, gênero, classe e ocupação, quanto instâncias de princípios culturais, valores e idéias que avaliam, orientam e constroem a significação percebida de fenômenos e que permitem classificá-los e inter-relacioná-los.

Sob a perspectiva da antropologia do consumo, os bens são codificados, portanto, com categorias e princípios que comunicam, por exemplo, o gênero e a classe social de seu possuidor, assim como valores dos quais compartilham, criando estruturas de identidade e ao mesmo tempo de diferenciação entre pessoas e grupos. A imagem de marca construída pela publicidade nos informa sobre os significados culturais que, de forma contínua, os bens de consumo incorporam a partir do mundo social, a comunicação publicitária desta imagem consiste em

\begin{abstract}
um canal através do qual o significado está constantemente fluindo, em seu movimento do mundo culturalmente constituído para os bens de consumo. Através do anúncio, bens antigos e novos estão constantemente destituindo-se de velhos significados e assimilando outros [...]. Nesta medida, a propaganda funciona para nós como um léxico dos significados culturais correntes. (MCCRACKEN, 2003, p. 109).
\end{abstract}

A teoria da estrutura móvel de emissão/recepção de significados culturais dos bens é questionada por Trindade (2014) que em seu estudo sobre os diferentes ethé publicitários que constituem a comunicação 
publicitária contemporânea, conceitua, no lugar da estrutura emissão/ recepção de significados, a idéia de circulação de significados culturais e ao invés de recepção neste mesmo processo, o autor nos fala de consumo das mensagens publicitárias, tal qual entendemos o consumo de bens simbólicos. Trindade argumenta que pensar a recepção da comunicação publicitária e, por conseguinte, dos significados culturais do mundo social codificados em mensagens como fim do processo, (como argumenta MCCRACKEN 2003), é ignorar o fato de que o interlocutor das mensagens enquanto consumidor rearticula os sentidos destas mensagens ao assimilá-las a partir de seu repertório cultural (que não é uníssono e linear, como se supunha em tempos de entendimento do consumidor a partir de um recorte demográfico que categorizava-o enquanto determinantes de gênero, faixa etária, procedência, mas cada vez mais heterogêneo, não-linear e não categorizável a partir destas determinantes) redefinindo o sentido que busca criar similaridade com o mundo social deste interlocutor projetado na composição da mensagem publicitária. Segundo Trindade:

Os ethé publicitários, assim, constituem-se na constante atualização dos valores presentes nos bens de consumo, identificados como valores simbólicos e culturais. Não se identificam mais com os pólos de emissão e recepção posicionados em oposição, mas sim com uma idéia de circulação, confluente de valores no consumo midiático na complexa rede comunicacional, em que tais estatutos da comunicação passam a atuar. (TRINDADE, 2014, p. 10).

O consumo opera, conforme a antropóloga Mary Douglas (2004), como um marcador social nas relações de poder entre indivíduos e grupos e estas marcas distintivas circulam, para além dos processos de interação física entre pessoas, nas interações do mundo digital - na internet - o consumidor hipermoderno se reposiciona na hierarquia das relações sociais, presenciais e digitais, não apenas entre pessoas, mas na interação com marcas e com o mercado produtor de bens como um todo.

Conforme Yanaze (2014) os consumidores enquanto atores sociais se empoderam com o advento da internet pela produção de autoridade por meio do diálogo. Para o autor, a interação promovida pelas plataformas tecnológicas assume o poder de delinear a sociedade atual, o que configura como vimos ao longo desta pesquisa, a midiatização digital, pois a rapidez na circulação de informações associada à liberdade de ex- 
pressão e necessidade de "opinar" sobre assuntos de todo tipo em pontos de contato com a marca e outros consumidores online, criam novos contornos, não apenas no âmbito do consumo, como na relação entre marcas e consumidores e nos processos de interação social mediados pelo consumo como marcador de identidades.

\section{A relação consumidor-marcas na era da midiatização digital}

Temos aqui novos contornos do consumo contemporâneo a partir da midiatização digital como processo interacional de referência - as relações de poder marcadas pelo consumo não operam de forma linear na rede digital, mas novas e emergentes identidades se formam com marcações sociais construídas pela relação dos consumidores-interlocutores das mensagens publicitárias das marcas e elas mesmas.

Se nas interações fora da rede digital os indivíduos se relacionam por meio de signos codificados em bens de consumo, como quer Baudrillard (1995), na rede digital, as relações entre estes indivíduos consumidores e as marcas, na forma como estes publicam comentários, opiniões e criticas sobre estas constituem marcações sociais para além da compra do produto.

Os consumidores se tornam, em tempos de mídias digitais, o que Tapscott (2010) denomina prossumers, ou consumidores co-criadores de produtos e serviços, onde a colaboração, comunidade e diálogo enfraquecem a hierarquia do mercado, pois os consumidores colaboram com o planejamento, a produção e mesmo a criação de comunicação sobre o produto, por meio do diálogo direto e abrangente proporcionado pela internet entre consumidores-interlocutores da mensagem publicitária entre si e entre estes consumidores-interlocutores e marcas.

O poder das comunidades online, a abrangência de seu discurso no processo de interação entre consumidores, fez com que a indústria buscasse se relacionar com maior proximidade de seu target, de forma a enfraquecer a hierarquia que toma as marcas como o 'topo da cadeia de consumo' e estabelecer novas relações de poder a partir dos processos de interação entre marcas e consumidores online. Conforme Tapscott:

Due to deep changes in technology, demographics, business, the economy, and the world, we are entering a new age where people participate in the economy like never before. This new participation has reached a tipping point where new forms of mass collaboration are changing how goods and services are invented, produced, marketed, and distributed on a global basis. (TAPSCOTT, 2010, p. 10). 
As mudanças acarretadas pela mídia digital como processo interacional de referência (BRAGA, 2012), levaram as marcas a tornar (se não de forma real, mas no discurso e processos de interação) o consumidor o protagonista das relações de consumo, concedendo-lhe o poder que este suscita nas interações ocorridas no meio digital (redes sociais, blogs, fan pages, fóruns, sites de marcas) de redefinir como devem ser produtos, serviços e, em especial, as comunicações publicitárias que instituem os pontos de contato do consumidor com a imagem de marca, seus valores, sua ética, seu posicionamento em relação a questões sociais e de relações de poder.

Mas o protagonismo do consumidor nas relações com marcas tem outros impactos sobre o consumo e sobre o consumidor em si, pois sua interação com estas marcas no universo da internet também proporciona uma triangulação - a dos consumidores entre si por meio da interação e manifestação de opiniões sobre marcas - a dos consumidores com as marcas e os códigos sociais de marcação identitária e estatutária resultantes desta interação com as marcas que são comunicados aos demais consumidores-interlocutores via redes sociais e demais pontos de interação na internet.

Se na vivência da realidade 'offline' (no mundo real, fora da internet), indivíduos enquanto consumidores adotam bens como marcadores sociais que os posicionam no mosaico social em termos de relações de poder e, se os bens são atualmente menos imperativos que as marcas, no mundo da internet a marcação social não se dá necessariamente pela exposição dos bens e marcas adotados (em fotos compartilhadas em redes sociais expondo o produto possuído, por exemplo), mas na relação que o consumidor desenvolve em processos de interação com as marcas nos pontos de contato do meio digital, nas fan pages de marcas, em blogs, fóruns, sites, comentários sobre marcas em todas as suas páginas em redes sociais que, embora não exponham se o consumidor realmente é comprador e usuário do produto em sua materialidade, demonstra o padrão que este expõe de relação com a marca, que passa a representar seu nível de 'propriedade' sobre os conteúdos simbólicos desta, o que engendra a constituição de sua identidade marcaria por meio dos conteúdos simbólicos, os valores e princípios defendidos por esta marca e a imagem percebida que os outros consumidores têm dela no meio digital.

Desde a postagem de opiniões sobre marcas que expressam o nível de conhecimento e interação do consumidor com elas - um post em rede social sobre a experiência com um champagne caro, um perfume 
de luxo, ou um carro importado, podem marcar socialmente um internauta como um connoisseur de um produto premium de preço proibitivo, de forma a categorizar seu status social, mesmo que este indivíduo não seja o possuidor do 'carrão', ou usuário de fato do perfume de luxo - até o julgamento sobre o caráter ético da propaganda de uma marca divulgada on e offline, constituem marcações sociais, não necessariamente do consumo do produto, mas em muitos casos, do consumo da comunicação do produto, em grande parte dos casos, do consumo da estética publicitária convertida em ética social.

As imagens-sonho geradas pela publicidade fluem pelo universo digital tal qual o fazem em outdoors, revistas, TV e são consumidas por interlocutores ávidos de novos signos estéticos e de marcação social, para que estes possam interagir com a imagem comunicada de marca representada na estética das campanhas publicitárias online e 'marcar', de suas identidades com signos codificados no dialogo sobre produtos, organizações e as marcas em si.

Este consumidor que não acredita mais em discursos que tentem mostrar diferenciais de produto, ou de imagem de marca pautados em qualidades de diferenciação - "use este produto e seduza", ou "consuma este produto e mostre que você é especial" - busca cada vez mais qualificações baseadas no propósito da marca como capital de diferenciação, para que ao consumir os significados que se busca "legítimos" no capital de valor das marcas, este também se valorize como uma marca que se diferencia por um propósito.

\section{A causa social como branding: legitimidade e verdade como estratégia}

No campo do branding, se perguntarmos por que algumas empresas são tão inovadoras como Apple, possuem uma imagem de marca tão consistente como Nike, ou são tão engajadoras como Harley Davidson, pensaremos em histórias singulares, como a superação de barreiras de Steve Jobs (sua exclusão da Microsoft), ou a iconicidade e perpetuação histórica da imagem da Harley Davidson. Mas por trás de diferenças, estas marcas, em seu sucesso junto ao consumidor, possuem um mesmo padrão: estas empresas têm princípios, ações e formas de comunicação convergentes.

Há 60 anos, toda a comunicação das empresas estava voltada para o 
produto. Nas suas características, qualidades, diferenciais e superioridades em relação aos seus concorrentes - era o momento do Marketing 1.0. Este momento começa a mudar nos anos 1970, quando as empresas começaram a se dirigir diretamente ao consumidor. Já nos anos 1969/1970 tem inicio o processo de substituição do produto pela imagem na sua comunicação, pois a televisão possibilitava a ampliação da produção de imagens, com vistas, na publicidade, para a diferenciação das marcas, já que se vivia a explosão de produtos cada vez mais homogêneos. Este processo traz, já nos anos 1990, a produção de imagens que, não diziam respeito ao produto, começando o descolamento da imagem do produto, onde apresentá-lo não é mais o objetivo principal.

A partir dos anos 1990, o consumidor passou a ser o centro das atenções. Com a comunicação cada vez mais individual e dirigida para o consumidor de seus produtos, o Marketing 2.0 buscava uma conversa mais próxima e dirigida ao seu público.

Mas isso também já mudou nos últimos anos, pela influência das novas mídias e novas tecnologias de comunicação digital. Nos últimos 10 anos as empresas começaram a entender seu papel de uma maneira diferente na sociedade. Elas começaram a entender que os consumidores também buscavam nas empresas um papel, antes relegado ao Estado, para ajudar a se posicionarem diante de temas cada vez mais complexos. Não bastava agora somente a finalidade financeira das empresas, mas como elas estavam se portando perante a sociedade e ao ambiente em que estavam inseridas. Surge ai o conceito de empresas Sustentáveis e o Marketing 3.0. Todos esses conceitos muito bem descritos por Philip Kotler em seu livro Marketing 3.0.

$\mathrm{Na}$ era deste "novo" tipo de Marketing, que foca em aspectos humanizadores e espiritualizados, uma das grandes mudanças ocorre no próprio consumidor - ele passou a ser também uma marca e agora a comunicação dele com as empresas se da em duas vias - ou seja, não é mais o velho modelo onde a empresa fala o que quer para um público que só ouve, agora, com as mídias sociais, esse consumidor passou a ter voz e influência sobre outros consumidores, sobre o produto e sobre o serviço das empresas.

Esse consumidor posiciona-se nas relações com as marcas também como uma marca. O meio digital converteu-se em um grande palco de representações individuais e coletivas de consumidores, onde o fluxo acelerado e a abrangência de circulação de informações amplia a efemeridade 
da realidade vivenciada, tanto em rede, quanto no mundo real. A necessidade da criação de marcações identitárias no meio digital tem o consumo da comunicação de marcas e dos conteúdos simbólicos destas a nova égide das representações sociais por meio do consumo. E nesse contexto, os significados sociais do presente imediato, o zeitgeist e os valores sociais que mais representam esse zeitgeist - imperativos na cultura digital, onde a necessidade de marcação identitária inclui a opinião e a adoção de posicionamentos, causas e a 'atitude' na forma do dialogo como determinantes para a constituição do self - são codificados em produtos e marcas pelo discurso institucional presente nas campanhas publicitárias e consumidos pelo consumidor-interlocutor do discurso publicitário como uma atualização pessoal na efemeridade da vivência social contemporânea.

Este consumidor-marca busca cada vez mais empresas com as quais possa desenvolver um diálogo "de igual para igual", numa relação onde a transparência é um ponto essencial para que os valores da marca sejam apreendidos não apenas em discursos publicitários superficiais, mas que realmente sejam visíveis e representados em toda a cadeia de contato com o consumidor.

Os lugares que ele frequenta, para onde viaja, quais produtos consome, tudo isso faz parte de seu universo de marca e tem que dizer alguma coisa sobre ele. Por isso, as empresas não podem simplesmente falar de seus produtos ( $\mathrm{O}$ que) e sim, serem mais profundas em seus posicionamentos - em seus Valores, afinal o consumidor-marca quer representar socialmente seus valores, portanto quer estar "associado" a uma empresa que comungue destes mesmos valores, ou pelo menos expresse uma parte do que ele, consumidor, quer se expressar para o mundo.

Kotler (2010) afirma que o consumidor atual "inverteu" a Pirâmide de Maslow. Sobre a famosa pirâmide, Kotler alega que o consumidor atual busca não apenas por autoestima, ou ego, mas também pela realização pessoal, espiritual e por um significado para sua existência. Nesse contexto, o consumidor-marca busca por signos dados pelas marcas que o ajudem a se posicionar moralmente e não só financeiramente, como exposição de seu status social. Afinal, o consumidor também tem a sua causa.

Uma causa pode ser pensada como uma bandeira de luta. Mas pensemos o que é uma causa para uma empresa. Numa analogia, uma causa se aproximaria do que uma empresa tem, ao menos em discurso, como Missão e Valores, muitas vezes bem descritos em pôsteres na sala da diretoria e disseminados pelos colaboradores. 
Se as causas defendidas por pessoas, como bandeiras de luta representam valores e imbuídos numa missão e objetivos, podemos pensar que para uma empresa, a causa precisa estar introjetada no seu sistema de crenças, no código de valores que estrutura, de fato sua missão, tem que fazer parte do que, no marketing, considera-se como sendo o seu DNA, o de seus fundadores e de seus principais controladores.

A causa que orienta todo o universo de valores sob os quais se constitui uma empresa, caracteriza o que seria, metaforicamente, sua alma e, essa causa, além de fazer parte do seu DNA, tem que respeitar alguns princípios, caso contrario, ela não conseguirá ser percebida pelo consumidor como legítima, pois, diferentemente de outras épocas, como na era de broadcasting, em que a imagem de marca era comunicada da marca para milhares de consumidores, na era digital, na comunicação 1 para 1, na individuação das interações e relacionamentos entre consumidor e marca, este consumidor que também se acredita marca, enxerga a marca de igual para igual, também como uma pessoa, que se trair sua confiança, fingir ser alguém que não é, ou tentar ludibriá-lo com uma imagem bonita sob um conteúdo ruim, será desmascarada por ele. E pior, publicamente, nas mídias sociais digitais.

O primeiro princípio, conforme o escritor Simon Sinek (2011), que tornou-se um "guru" entre profissionais de marketing, é que a causa empunhada pela marca tem que ser Verdadeira. Verdadeira significa que ela não pode ser uma construção fictícia gerada por um publicitário talentoso. Ela precisa existir. Quem criou a empresa e seus produtos e serviços, tem que de fato acreditar que ela é algo pelo qual vale a pena lutar e comunicar como sua bandeira. Se não for verdadeira, se não passar de um desejo do que gostaria de ser, não será suficiente. A verdade da causa, quando parte da marca, se estabelece de dentro para fora e em toda a cadeia de ponto de contato com o consumidor, fornecedores e organizações. Quando ela é verdadeira, passa a pautar as ações da empresa, e todas as decisões são orientadas por ela, o que cria um sentido de verdade que perpassa todos os stakeholders. Ela está presente desde o corte de um produto ate a forma como as lideranças lidam com seus colaboradores.

O segundo princípio é que ela tem que ser Relevante. Não basta ser verdadeira, se não encontra eco nos valores das pessoas que interagem com a empresa. A relevância tem a ver, no caso de uma empresa, com ser algo que tenha impacto na vida das pessoas, ou que dialogue com elementos consistentes da realidade vivenciada pelas pessoas. A Relevância 
permite que a causa seja um elo de conexão, pois abre um diálogo entre consumidor e marca pela identificação, por parte dos consumidores, de algo que lhes toca de verdade, permitindo o desenvolvimento de vínculos.

O terceiro princípio de Sinek (2011) é que a causa tem que ser Engajadora. Ou seja, ela tem que ser capaz de fazer as pessoas se movimentarem por ela. Se incomodarem com ela. Falarem sobre ela. Esse engajamento e' essencial para que as pessoas estejam envolvidas com sua marca e possam ser, quem sabe, embaixadoras de sua marca.

A importância da teoria de Sinek é permitir a criação de laços entre empresa e consumidor. E essa afinidade só traz benefícios. Lealdade do consumidor, recompra, maiores gastos com sua empresa. E melhor percepção de qualidade de seus produtos e serviços. Mas ter uma Causa respeitando seus três princípios não é suficiente. É necessário comunicar isso de forma eficiente. As empresas lideres falam de seu Propósito e suas Crenças primeiro. Depois elas falam de Como e o Que fazer para chegar lá.

A importância dos princípios de Sinek, que defende a idéia de que "as pessoas não compram o que você faz. Mas porque você faz", converge para a lógica da antropologia do consumo, conforme Douglas (2004), de que para além de investigar o que as pessoas compram, se deve entender porque elas compram.

Nunca o propósito foi tão determinante na construção de imagem de marca, pois nunca as marcas precisarem ter valores e missão sintetizados numa causa, de forma tão verdadeira, relevante e engajadora.

Um quarto elemento que não está presente na lógica de Sinek, mas que acreditamos ser essencial para a construção de marcas na Era das Causas, é a relação com o Zeitgeist, o momento presente. Isso não significa embarcar numa onda momentânea que passará e levará junto todo o arcabouço simbólico construído pela marca. O momento presente é a era vivenciada pelo consumidor, com os elementos que constituem a cosmologia cultural da contemporaneidade, que permite tocar em pontos que estão na pauta recorrente das vidas das pessoas e que permeiam seu repertório.

Os elementos do zeitgeist devem estar presentes no discurso da marca, na representação de seu propósito, até mesmo para que se consiga construir a relevância mencionada por Sinek.

A Harley Davidson, por exemplo, marca centenária que evoca a liberdade, foi sonho de consumo de muitos jovens rapazes de déca- 
das passadas, que fantasiavam cruzar as estradas do país e do mundo numa Harley. Mas na era atual, onde o empoderamento feminino é uma macrotendência mundial, o discurso e o produto voltados também às mulheres estão cada vez mais presentes, a exemplo dos motoclubes de mulheres que nascem nas próprias lojas da marca no Brasil, como a Ladies of the Road, motoclube de mulheres que nasceu na Harley Davidson brasileira.

Uma causa que reverbere e toque emocionalmente o consumidor, precisa criar vínculos com as mudanças socioculturais que rearticulam valores estruturados como o respeito pelas pessoas (lema da marca Toyota), que se outrora poderia significar no Brasil tratar bem seu cliente e dar-lhe atenção e ouvidos, hoje diz respeito também e sobremaneira, a amparar a diversidade - étnica, sexual, econômica - como preceito de respeito humano.

\section{Considerações finais}

O que vemos atualmente no Brasil (e também em países do exterior) é que a causa como estratégia de marketing tornou-se uma tendência utilizada à revelia por marcas e organizações, mas nem sempre de forma inteligente e eficaz.

Conforme Perez, o volume e qualidade de informações disponíveis por meio das novas tecnologias de comunicação, associado a um numero crescente de ofertas de produtos, originou maior conscientização e criticidade em ações e manifestações de consumidores. Segundo a autora: "O mundo do consumo e das marcas nunca enfrentou tantas manifestações de indignação e repulsa. A ética está em pauta e congrega pessoas no mundo todo, assim como a estética manifestase no design, na cenografia da embalagem e nas campanhas publicitárias." (PEREZ, 2008, p. 129).

A busca por ética e transparência configura também uma busca por legitimidade na construção da imagem das marcas. Significa que o consumidor, cada vez mais crítico, com acesso a informações e exigente em termos da veracidade de discursos, percebe quando uma marca não possui a causa defendida em seu DNA, pois, tal qual um organismo humano, este DNA estaria presente na totalidade do que se tem contato com as marcas e não é o que vemos em grande parte delas hoje.

A marca que realmente possui uma causa, a tem como orientação 
ideológica a determinar sua conduta, organicamente, em toda a cadeia de ponto de contato com consumidores, colaboradores, fornecedores.

Muitas marcas estão "aderindo a causas" numa estratégia desesperada em prol de conquistar o consumidor, este, descrente das estratégias de branding convencionais, pautadas na lógica da diferenciação. Mas não percebem que uma causa é uma bandeira ideológica cujo detentor necessita, acima de tudo, provar-se idôneo e totalmente engajado a ela, em todas as suas formas de funcionamento social e expressão, para que a sociedade lhe atribua legitimidade.

A incoerência de comportamentos e representações de marcas que aderem a causas, faz com que "o tiro saia pela culatra", ou seja, os consumidores, ao perceberam incoerências no alinhamento das marcas com seu discurso ideológico de apoio a causas, passam a desacreditar delas, o que faz com que, de indiferente a uma marca, o consumidor se torne avesso a ela, ou mesmo "hater" (combatendo-a nas redes sociais), configurando um erro estratégico para marcas que, embora busquem inovar e se alinhar com a lógica do consumidor 3.0 de Kotler, não percebam a grande mudança ocorrida junto à identidade do consumidor na era das mídias digitais - ele enxerga-se como um igual - ele, enquanto marca, não é mais seduzido, ou conquistado com discursos superficiais, ele busca a autenticidade e exige a legitimidade das marcas, pois enxerga-se como marca também.

\section{REFERÊNCIAS}

BAUDRILLARD, Jean. A Sociedade do consumo. trad. de Artur Mourão. Rio de Janeiro, Editora Elfos, 1995.

BRAGA, José Luis. Interação como Contexto da Comunicação. Revista Matrizes. Ano 6. nº 1 - jul./dez. 2012 - São Paulo.

BRANDINI, Valéria. A Era das causas. O propósito como capital na estética

Publicitária. Relatório de Pesquisa de Pós Doutorado. Escola de Comunicações e Artes da Universidade de são Paulo. Mimeo. 2016.

DOUGLAS, Mary \& ISHERWOOD, Baron. O mundo dos bens: para uma antropologia do consumo. Rio de Janeiro. Editora UFRJ. 2004.

HEPP, Andreas. As configurações comunicativas de mundos midiatizados: pesquisa da midiatização na era da mediação de tudo. Revista Matrizes. V1 jan-jun 2015. São Paulo. 
KOTLER, P.; KARTAJAYA, H.; SETIAWAN, I. Marketing 3.0: as forças que estão definindo o novo marketing centrado no ser humano. Rio de Janeiro: Elsevier, 2010.

MACCRACKEN, Grant. Cultura e consumo. Novas abordagens ao caráter simbólico dos bens e das atividades de consumo. Rio de Janeiro. Mauad. 2003.

PEREZ, Clotilde. Consumidores mais complexos e exigentes. Um desafio ético e estético para as marcas contemporâneas. eGesta, v. 4, n. 3, jul.-set./2008 SINEK, Simon. Start With Why - How great leaders inspire everyone to take action. Penguin Books. London. 2011.

TAPSCOTT, Don; WILLIAMS, Anthony D. The prosumers. In: Wikinomics: how mass collaboration changes everything. New York, USA: Penguin Books, 2010.

TRINDADE, Eneus. Mediações e Midiatizações do Consumo. Intercom -XXXVII Congresso Brasileiro de Ciências da Comunicação - Foz do Iguaçu, PR - 2014.

TRINDADE, Eneus e SOUZA, Livia. Ethé publicitários e consumo: confluências discursivas na circulação midiática. Revista Comunicação Midiática, v.9, n.1, p.120133, jan./abr. 2014.

TRINDADE, Eneus e AUGUSTO JR, Silvio N. Aprofundamentos de aspectos conceituais entre as mediações culturais e a midiatização do consumo alimentar. Trabalho apresentado no VI Pró-Pesq PP-Encontro Nacional de Pesquisadores em Publicidade e Propaganda. Realizado na ECA/USP no período de 27 a 29 de maio de 2015.

YANAZE, Mitsuro. VELLOSO, Viviane. O consumidor insatisfeito em tempo de redes sociais. ECCOM, v. 5, n. 9, jan./jun. 2014. 